\title{
GENUS HYSTRIX.-LinN.
}

DENTAL FORMULA.

$$
\text { Incisive } \frac{2}{2} ; \quad \text { Canine } \frac{0-0}{0-0} ; \quad \text { Molar } \frac{4-4}{4-4}=20 \text {. }
$$

Superior incisors, on the anterior portion, smooth, cuneiform at their extremity ; inferior incisors, strong and compressed.

Molars, compound, with flat crowns, variously modified by plates of enamel, between which are depressed intervals.

Head, strong ; snout, thick and tumid; ears, short and round; tongue, bristled with spiny scales; fore-feet, four-toed; hind-feet, five-toed; all the toes armed with powerful nails.

Spines on the body, sometimes intermixed with hair; tail, moderately long, in some species of the genus, prehensile.

Herbivorous, feeding principally on grain, fruits, roots, and the bark of trees-dig holes in the earth, or nestle in the hollows of trees.

The generic name is derived from the Greek word, iørpis, (hustrix,) a porcupine-is, (hus,) a hog, and Aprs, (thrix,) a bristle.

There are two species in North, and three in South America, one in Southern Europe, one in Africa, and one in India.

\section{H Y S T R I X DOR S A T A.- LINN.}

\section{Canada Porcupine.}

PLATE XXXVI-MALE.

H. spinus brevibus, vellere sublatentibus; sine jubea; capite et collo setis longis vestitis; colore inter fulvum et nigrum variante.

CHARACTERS.

Spines, short, partially concealed by long hair; no mane; long bristles on the head and neck; colour, varying between light-brown and black. 


\section{$2 \mathrm{BHL}$ Biodiversity Heritage Library}

Audubon, John James and Bachman, John. 1851. "Genus Hystrix." The quadrupeds of North America 1, 277-277. https://doi.org/10.5962/p.322429.

View This Item Online: https://www.biodiversitylibrary.org/item/108513

DOI: https://doi.org/10.5962/p.322429

Permalink: https://www.biodiversitylibrary.org/partpdf/322429

\section{Holding Institution}

Duke University Libraries (archive.org)

\section{Sponsored by}

Duke University Libraries

\section{Copyright \& Reuse}

Copyright Status: Not provided. Contact Holding Institution to verify copyright status.

This document was created from content at the Biodiversity Heritage Library, the world's largest open access digital library for biodiversity literature and archives. Visit BHL at https://www.biodiversitylibrary.org. 